\title{
Hubungan Kondisi Kerja, Kepuasan Kerja, dan Prestasi Kerja Pekerja Konstruksi di Jakarta
}

\author{
Bimmo Dwi Baskoro $^{1 *}$, Osrita Hapsara ${ }^{2}$, Sri Mulyono ${ }^{3}$ \\ ${ }^{1}$ Sekolah Tinggi Manajemen Labora, Jakarta, Indonesia \\ ${ }^{2}$ Universitas Batanghari, Jambi, Indonesia \\ ${ }^{3}$ Institut Daarul Qur'an, Tangerang, Indonesia \\ *correspondence email: bimmodibi@gmail.com
}

\begin{abstract}
This study analyses the effect of work on job performance with job satisfaction as a mediating variable. A total of 210 respondents representing construction companies in Jakarta were involved in this study. PLS-SEM (Partial Least Square Structural Equation Modeling) was used to test the research model. Working conditions do not have a significant effect on work performance. However, it is known that job satisfaction mediates the relationship between working conditions and work performance. This study has several limitations so that the results of the study cannot be generalized to other sectors.
\end{abstract}

Keywords: working condition, job performance, job satisfaction, construction.

\section{Pendahuluan}

Pelatihan, pengembangan, dan prestasi kerja dianggap sebagai elemen penting di bawah disiplin psikologi industri (Armstrong, Atkin-Plunk, \& Wells, 2015; Borman, 2004). Kinerja pekerja sangat penting bagi perusahaan mana pun karena pada akhirnya mengarah pada kesuksesan perusahaan (Agarwal, 2014). Kemajuan teknologi telah menghasilkan peningkatan yang luar biasa dalam ekonomi dan gaya hidup modern dimana pada saat yang sama, telah menyebabkan peningkatan persaingan antar organisasi (Law \& Guo, 2016; Nilsen \& Ringholm, 2019). Hal ini telah menyebabkan banyak manajer senior dan pembuat kebijakan untuk lebih menekankan pada mempertahankan posisi kompetitif di pasar (Faragher, Cass, \& Cooper, 2005). Penelitian sebelumnya menjelaskan bahwa kepuasan terjadi ketika tempat kerja mengembangkan kualitas tertentu yang mengarahkan pekerja untuk bekerja lebih baik (Judge \& Larsen, 2001). Oleh karena itu, kondisi kerja yang sesuai harus ditetapkan bagi karyawan untuk menjalankan tanggung jawabnya dengan memanfaatkan potensi mereka sepenuhnya dan pada saat yang sama memberikan layanan berkualitas kepada pelanggan (Masa'deh, Obeidat, \& Tarhini, 2016). Oleh karena itu, kepuasan pekerja mengarah pada kepuasan pelanggan (Atamba, 2019). Beberapa peneliti mendukung gagasan bahwa ketika manajer mendukung karyawan, mereka bekerja lebih baik karena tingkat stres yang lebih rendah dan mendorong interaksi kepada supervisor langsung mereka (Kiazad, Kraimer, \& Seibert, 2019; Taghipour \& Dejban, 2013). Prestasi kerja yang dipengaruhi oleh berbagai faktor terwujud ketika seorang individu berhasil mencapai tugas yang diberikan kepadanya dengan hambatan yang lebih sedikit di tempat kerja (Matsuo, 2019; Yozgat, Yurtkoru, \& Bilginoğlu, 2013).

Penelitian perilaku organisasi sangat membutuhkan untuk memeriksa peran mediasi kepuasan kerja antara hubungan kondisi kerja dan prestasi kerja (Yuen, Loh, Zhou, \& Wong, 2018). Penelitian tentang kondisi kerja organisasi di negara berkembang masih kurang memadai khususnya di Indonesia. Para ahli sebelumnya terutama berfokus pada berbagai faktor untuk meningkatkan kinerja karyawan seperti pelatihan, keamanan / keselamatan, jam kerja dan desain ulang pekerjaan (Kiazad et al., 2019; Masa'deh et al., 2016). Dalam Job Characteristics Theory (JCM), kepuasan terjadi ketika tempat kerja memberikan energi pada kualitas yang menginspirasi secara alami di antara para pekerja yang mengarahkan pekerja untuk bekerja lebih baik di tempat kerja (Hackman \& Oldham, 1976; Raziq \& Maulabakhsh, 2015). Teori tersebut menetapkan kondisi dimana individu diprediksi akan berhasil dalam pekerjaan mereka (Bashir, Amir, Jawaad, \& Hasan, 2020). Penelitian ini mengusulkan bahwa karyawan akan dapat bekerja lebih baik pada pekerjaan jika mereka diberikan kondisi kerja yang lebih baik dari sebelumnya. Penelitian ini juga bertujuan untuk mengetahui apakah tingkat kepuasan kerja seorang karyawan berperilaku sebagai mediator antara hubungan tersebut.

Berdasarkan teori JCM, fokus penelitian ini adalah untuk mengetahui pengaruh kondisi kerja terhadap prestasi kerja. Secara khusus, penelitian ini berfokus pada peran mediasi kepuasan kerja pada hubungan kondisi kerja dan prestasi kerja khususnya di sektor konstruksi di Jakarta. Oleh karena itu, untuk mengatasi kesenjangan penelitian yang sudah diidentifikasi, penelitian ini berfokus pada jalur mediasi dimana kondisi kerja mengarah pada peningkatan kinerja kerja melalui kepuasan kerja, karena tekanan yang meningkat dari pemangku kepentingan suatu organisasi, kondisi kerja menjadi keharusan bagi perusahaan untuk dipertimbangkan (Aziz, Kumar, Rathore, \& Lal, 2015; Górny, 2017). Hal ini karena kondisi kerja telah muncul sebagai elemen yang berpengaruh terhadap kinerja karyawan di tempat kerja mana pun (Jiménez, Winkler, \& Dunkl, 2017). Selain itu, tekanan pemerintah di Indonesia melalui regulasi yang semakin meningkat untuk kondisi kerja yang lebih baik, para pegawai saat ini juga cenderung menuntut 
kondisi kerja yang lebih baik untuk melaksanakan pekerjaannya (Kiazad et al., 2019; Lu, Lu, Gursoy, \& Neale, 2016). Oleh karena itu, manajer sumber daya manusia harus mencapai target lain dalam hal perbaikan kondisi kerja (Akhtar, Naheed, Akhtar, \& Farooq, 2018). Kondisi kerja yang buruk cenderung mempengaruhi kepuasan dan kinerja pekerja di tempat kerja (Guan \& Frenkel, 2019). Para ahli menyatakan bahwa konstruksi endogen yang paling penting dalam psikologi organisasi dan industri berkaitan dengan kinerja pekerjaan (Jung \& Yoon, 2015). Penelitian terbaru telah menyelidiki pengaruh kondisi kerja terhadap kepuasan karyawan (Agbozo, Owusu, Hoedoafia, \& Y. B. Atakorah, 2017), pengaruh kehadiran, kondisi kerja, dan absensi terhadap produktivitas (Strömberg, Aboagye, Hagberg, Bergström, \& Lohela-Karlsson, 2017). Mereka juga fokus pada bagaimana kolaborasi lingkungan kerja dan kepribadian mempengaruhi kinerja setiap karyawan (Mustafa \& Ali, 2019). Namun, sangat sedikit peneliti yang menekankan kepuasan kerja sebagai faktor penentu prestasi kerja (Yuen et al., 2018).

Penelitian ini berfungsi sebagai studi awal untuk menyelidiki pengaruh kondisional tidak langsung kepuasan kerja antara hubungan kondisi kerja dan prestasi kerja di sektor konstruksi di Jakarta. Studi ini berkontribusi pada literatur di berbagai tingkatan. Pertama, penelitian ini menunjukkan bahwa hubungan antara kondisi kerja dan prestasi kerja secara tidak langsung tetapi dimediasi melalui kepuasan kerja. Kedua, model penelitian ini menemukan interaksi yang lebih kompleks melalui peningkatan kinerja karyawan dalam pekerjaan, khususnya melalui kepuasan kerja. Ketiga, penelitian ini melengkapi perspektif teoritis teori JCM dengan menyelidiki pengaruh kondisi kerja. Keempat, penelitian ini dilakukan di sektor konstruksi dimana penelitian sebelumnya belum pernah dilakukan dengan menggunakan variabel yang digunakan pada studi ini.

\section{Tinjauan Pustaka dan Pengembangan Hipotesis \\ Kondisi Kerja dan Kinerja}

Untuk setiap bisnis, kinerja telah dinilai oleh fundamental bisnis yang berkaitan dengan penjualan, pendapatan atau pendapatan (Osman, Shariff, \& Lajin, 2016). Namun, indikator non finansial juga penting untuk dipertimbangkan misalnya, menyelidiki kinerja bisnis yang berkaitan dengan sumber daya manusia seperti kepuasan, motivasi, dan absensi (Nilsen \& Ringholm, 2019). Sebuah organisasi perlu menghargai karyawannya sehingga mereka dapat bekerja secara efisien, serta mempertahankan posisi kompetitif mereka di pasar (Imran, Fatima, Zaheer, Yousaf, \& Batool, 2012). Lebih lanjut, prestasi kerja diartikan sebagai cara pekerja melaksanakan tugas-tugas organisasi, juga menghubungkan perilaku pekerja dengan norma perusahaan itu sendiri (Imran et al., 2012). Sebuah literatur yang substansial telah dibuat tentang lingkungan di mana kondisi kerja mempengaruhi kesejahteraan mental dan fisik (Baruch-Feldman, Brondolo, Ben-Dayan, \& Schwartz, 2002). Sifat emosional dalam bekerja yang dianggap tidak menyenangkan telah cukup dijelaskan pada penelitian sebelumnya. Beberapa studi telah mengungkapkan keadaan kelelahan yang tidak normal dan ketegangan emosional yang buruk di antara individu karena lingkungan kerja yang buruk (Røssberg, Eiring, \& Friis, 2004). Tempat kerja yang buruk ternyata terkait dengan masalah kehadiran, berkurangnya kepuasan kerja, keluhan fisik, kelelahan, dan kinerja kerja yang buruk (Gulliver, Towell, \& Peck, 2003). Tempat kerja yang buruk kemungkinan besar merupakan salah satu alasan mendasar untuk tingkat pergantian staf yang tinggi dan kepuasan serta kinerja yang buruk (Mustafa \& Ali, 2019; Røssberg et al., 2004). Faktor tempat kerja dan kepuasan juga dapat menjadi tolok ukur yang berguna untuk menilai perubahan dan kemajuan pekerjaan di masa depan. Selain itu, kondisi dan lingkungan kerja didorong untuk dapat meningkatkan sikap pekerja yang mengarah pada kinerja yang lebih baik (Day \& Bedeian, 1991). Peningkatkan prestasi kerja karyawan secara keseluruhan di tempat kerja berhubungan dengan kondisi kerja yang dialami (Bashir et al., 2020). Fenomena ini juga didukung oleh JCM bahwa kepuasan terjadi ketika kondisi kerja mendorong motivasi yang semakin menuntun para pekerja untuk bekerja lebih baik. Sesuai dengan pembahasan di atas, hipotesis pada penelitian ini sebagai berikut:

H1: Kondisi kerja berhubungan positif dengan prestasi kerja.

\section{Kepuasan Kerja dan Prestasi Kerja}

Konsep kepuasan kerja telah banyak diteliti terkait dengan perilaku organisasi serta desain pekerjaan (Mustafa \& Ali, 2019). Menurut Herzberg (1959) dalam Ahmed (2010), teori yang disebut sebagai "teori dua faktor" yang berkaitan dengan kepuasan kerja. Dia menyatakan ketidakpuasan dan kepuasan sebagai kejadian yang tidak berhubungan. Selain itu, kejadian-kejadian yang berkaitan dengan faktor ekstrinsik dan intrinsik disebut sebagai "motivator", dimana faktor internal seperti pengalaman kerja terkait dengan kepuasan (Guan \& Frenkel, 2019). Kepuasan seperti itu termasuk tanggung jawab, pengakuan, prestasi, dan pekerjaan. Sedangkan faktor eksternal yang disebut dengan hygiene factor terdiri dari kebijakan perusahaan, gaji, dan pengawasan (Nilsen \& Ringholm, 2019). Aspek kepuasan kerja yang mempengaruhi kinerja merupakan aspek tertua dimana Bakotić \& Fiskovića (2013) melaporkan bahwa peningkatan moral pekerja akan meningkatkan produktivitas mereka. Lebih lanjut, Judge \& Larsen (2001) merekomendasikan bahwa penelitian sebelumnya yang berkaitan dengan kepuasan kerja dan kinerja dikaitkan dengan tujuh model. Dengan demikian, hal ini mendorong optimisme yang dibangun kembali tentang kemungkinan menemukan hubungan penting antara kepuasan kerja dan prestasi kerja (Wright, Cropanzano, \& Bonett, 2007). 
Berbagai peneliti telah mendefinisikan kepuasan kerja. Menurut Hoboubi et al. (2017), kepuasan kerja berkaitan dengan seorang karyawan memiliki arah yang efektif terhadap pekerjaan / pekerjaannya. Kepuasan kerja telah banyak dimanfaatkan oleh banyak peneliti dan dijelaskan sebagai keadaan yang diinginkan dimana seseorang mencapai nilai-nilai kerja (Trivellas, Reklitis, \& Platis, 2013). Lebih lanjut, ada pendapat bahwa jika karyawan tidak puas mereka merasa tidak jelas tentang pekerjaannya, merasa bahwa atasan kurang memperhatikan mereka, menganggap lingkungan kerja meragukan yang dapat menyebabkan karyawan merasa bahwa mereka tidak termasuk sebagai bagian aktif dari organisasi (Armstrong et al., 2015). Gul et al. (2018) menyatakan kepuasan memiliki hubungan positif dengan peluang karyawan dalam bekerja. Selanjutnya, peneliti lain menemukan kepuasan memiliki hubungan yang positif dengan kinerja karyawan (Inuwa, 2016). Penelitian yang dilakukan pada karyawan telekomunikasi di Pakistan oleh Bashir et al. (2020) menemukan bahwa kondisi kerja dan prestasi kerja dimediasi oleh kepuasan kerja. Oleh karena itu, sesuai dengan pembahasan di atas, hipotesis selanjutnya (seperti pada Gambar 1) sebagai berikut.

H2: Kepuasan kerja memediasi hubungan antara kondisi kerja dan prestasi kerja.

\section{Hasil}

\section{Confirmatory Factor Analysis (CFA)}

Tabel 1 menunjukkan faktor loading dari semua item yang mengukur variabel laten masing-masing yang ada dalam model teoritis bahwa tidak terdapat masalah multikolinearitas yang merupakan indikasi yang sangat positif untuk dilanjutkan ke pengujian mediasi. Model struktural yang menggambarkan pengaruh langsung kondisi kerja dan efek mediasi kepuasan kerja terhadap prestasi kerja ditunjukkan pada Gambar 1.

Tabel 1

Rangkuman CFA

\begin{tabular}{|l|r|r|r|r|}
\hline & Kepuasan Kerja & Kondisi Kerja & Prestasi Kerja & VIF Statistics \\
\hline KK1 & 0,921 & & & 2,682 \\
KK3 & 0,821 & & & 1,634 \\
KK4 & 0,836 & & & 2,133 \\
\hline Kondisi1 & & 0,773 & & 1,609 \\
Kondisi2 & & 0,709 & & 1,235 \\
Kondisi5 & & 0,899 & & 1,740 \\
\hline PK1 & & & 0,708 & 1,396 \\
PK2 & & & 0,756 & 1,459 \\
PK3 & & & 0,764 & 1,971 \\
PK5 & & & 0,714 & 1,981 \\
\hline
\end{tabular}

Sumber: data olahan

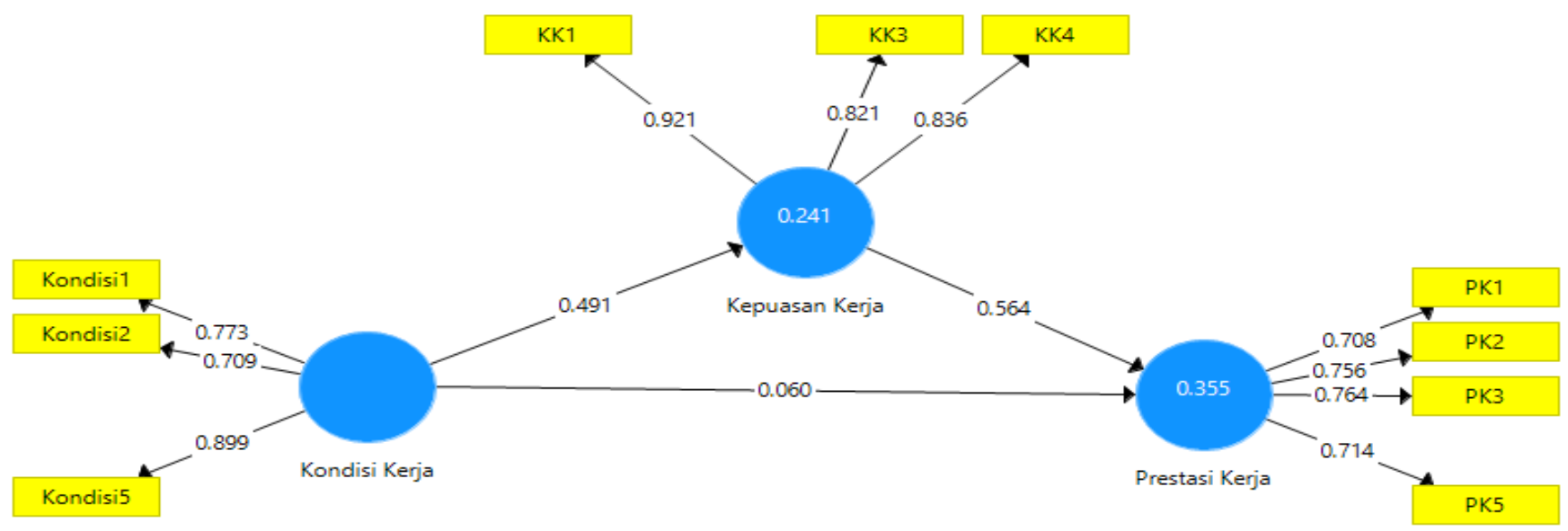

Sumber: data olahan

\section{Gambar 1 \\ Model Struktural $(n=210)$}

Tabel 2 melaporkan composite reliability, Average Variance Extracted (AVE), Mean, nilai Standard Deviation untuk kondisi kerja, prestasi kerja, dan kepuasan kerja. Karena semua variabel laten diukur melalui skala yang telah ditetapkan sebelumnya, validitas dapat digunakan. Hal ini dapat dilihat pada Tabel 2 bahwa composite reliability untuk semua variabel laten melebihi batas yang direkomendasikan 0,70 dimana menunjukkan bahwa terdapat divergent validity (Hair et al., 2019). Selain itu, hal ini dapat dinilai bahwa Average Variance Extracted 
(AVE) untuk semua variabel lebih besar dari cut-off point 0,50 yang menunjukkan bahwa indikator telah mewakili konstruk latennya.

Tabel 2

Hasil Reliabilitas dan Validitas

\begin{tabular}{lcrrrr}
\hline \multicolumn{1}{c}{ Variabel } & $\boldsymbol{C} \boldsymbol{\alpha}$ & \multicolumn{1}{c}{$\boldsymbol{A} \boldsymbol{E}$} & $\boldsymbol{M e a n}(\boldsymbol{S D})$ \\
\hline Kepuasan Kerja & & 0,824 & 0,895 & 0,740 & $4,19-4,22(0,58-0,68)$ \\
Kondisi Kerja & & 0,716 & 0,839 & 0,637 & $3,95-4,07(0,49-0,58)$ \\
Prestasi Kerja & & 0,721 & 0,825 & 0,542 & $4,00-4,28(0,61-0,72)$ \\
\hline
\end{tabular}

Keterangan: $\mathrm{C} \alpha=$ Cronbach's alpha $; \mathrm{CR}=$ Composite Reliability; $\mathrm{SD}=$ Standard Deviation

Sumber: data olahan

Pengujian validitas diskriminan melalui nilai rasio Hetero-trait Mono-trait (HTMT) yang memiliki kisaran yang direkomendasikan kurang dari 0,9 (Henseler, Ringle, \& Sarstedt, 2015). Hasil pada Tabel 3 menunjukkan bahwa semua nilai untuk rasio HTMT di semua variabel laten kurang dari 0,90 yang menunjukkan bahwa korelasi indikator dalam variabel laten yang sama lebih besar daripada korelasi indikator di seluruh variabel yang dapat menggambarkan model teoritis. Nilai NFI (Normed Fit Index) sebesar 0,623 menggambarkan keseluruhan model teoritis yang diajukan pada penelitian ini dan memenuhi kecukupan model (Hair, Sarstedt, Hopkins, \& Kuppelwieser, 2014). Nilai SRMR (Standardized Root Mean Square Residual) sebesar 0,120 dimana dapat dikatakan fit. Hasil tersebut sebagaimana saran dari Hu \& Bentler (1999), model persamaan struktural dapat dikatakan fit jika nilai SRMR kurang dari 0,100 dan model dinyatakan tidak layak jika nilai SRMR lebih besar dari 0,150.

Tabel 3

Hasil Rasio HTMT dan Validitas Diskriminan

\begin{tabular}{lccc}
\hline & Kepuasan Kerja & Kondisi Kerja & Prestasi Kerja \\
\hline Kepuasan Kerja & & & \\
Kondisi Kerja & 0,608 & 0,459 & \\
Prestasi Kerja & 0,750 & & \\
\hline
\end{tabular}

Sumber: data olahan

Tabel 4 Menyatakan hasil analisis jalur dan mediasi. Hasil statistik menunjukkan bahwa Kondisi Kerja tidak berpengaruh signifikan dan positif terhadap Prestasi Kerja $(\beta=0,060)$ pada tingkat signifikansi 5\%. Oleh karena itu, hipotesis 1 (H1) ditolak. Hasil penelitian juga menunjukkan bahwa Kondisi Kerja berpengaruh positif terhadap Kepuasan Kerja $(\beta=0,491)$ dan Kepuasan Kerja secara signifikan berbanding lurus dengan Prestasi Kerja $(\beta=0,564)$. Selain itu, efek tidak langsung menunjukkan bahwa Kepuasan Kerja memediasi total hubungan antara Kondisi Kerja dan Prestasi Kerja $(\beta=0,277)$.

Tabel 4

Rangkuman Analisis Jalur

\begin{tabular}{llrcl}
\hline Hipotesis & Hubungan & $\boldsymbol{\beta}$ & $\boldsymbol{p}$ values & Keterangan \\
\hline H1 & Kondisi Kerja $\rightarrow$ Prestasi Kerja & 0,060 & 0,203 & Tidak Signifikan \\
H2 & Kondisi Kerja $\rightarrow$ Kepuasan Kerja $\rightarrow$ Prestasi Kerja & 0,277 & 0,000 & Signifikan \\
\hline
\end{tabular}

Sumber: data olahan

Penelitian ini membawa temuan yang baru dengan menyelidiki hubungan antara Kondisi Kerja, Kepuasan Kerja, dan Prestasi Kerja. Penelitian ini juga memberikan berkontribusi pada penelitian sebelumnya. Pertama, menurut hasil studi diketahui bahwa kondisi kerja tidak berhubungan pada prestasi kerja yang lebih tinggi (H1). Kedua, kepuasan kerja memediasi hubungan positif antara kondisi kerja dengan prestasi kerja (H2). Hipotesis pertama bertolak belakang dengan penelitian Bashir et al. (2020). Namun, hipotesis pertama senada dengan penelitian yang dilakukan oleh Al-Omari \& Okasheh (2017). Indikator kondisi kerja yang terdiri dari kebebasan kebisingan, iklim kerja (misalnya suhu dan kelembaban), risiko kecelakaan, lingkungan bebas bahaya (semisal bahan kimia, asap, dan lainnya), dan lingkungan bersih tidak berkorelasi positif dengan prestasi kerja. Kondisi kerja pada konteks pekerja konstruksi pada penelitian ini tidak berhubungan dengan prestasi kerja. Secara umum, prestasi kerja yang ditunjukkan dalam bidang konstruksi terkait dengan kinerja biaya proyek, penyelesaian proyek tepat waktu, mutu, aspek keselamatan dan kesehatan kerja (K3), dan kinerja lingkungan (Kissi, Agyekum, Adjei-Kumi, Caleb, \& Micheal, 2020). Hasil yang tidak signifikan ini dikarenakan pekerja konstruksi dalam penelitian ini tidak melihat faktor kondisi kerja yang mempengaruhi kinerja mereka. Faktor lokasi proyek yang terletak di tengah kota juga memberikan kesan rasa aman sehingga kondisi kerja di lokasi proyek tidak memberikan pengaruh terhadap kinerja. 
Hasil penelitian yang berkaitan dengan peran mediasi kepuasan kerja menunjukkan bahwa kondisi kerja perusahaan membantu dalam meningkatkan kinerja karyawan. Selain itu, perusahaan harus fokus dalam memberikan kondisi kerja yang lebih baik kepada karyawannya untuk menjalankan aktivitas dan tugas sehari-hari untuk meningkatkan tingkat kepuasan karyawan (Jiménez et al., 2017; Mustafa \& Ali, 2019) tetapi hal ini tidak bisa menjadi satu-satunya hal yang penting bagi staf mereka. Karyawan mungkin merasa kurang termotivasi karena alasan lain dan mungkin tidak bekerja lebih baik di tempat kerja (Strömberg et al., 2017). Studi ini secara signifikan memberikan kontribusi kepada akademisi dan praktisi dengan mengidentifikasi jalur dimana kondisi kerja cenderung terkait dengan prestasi kerja yang dimediasi kepuasan kerja. Peran mediasi yang terkait dengan kepuasan kerja sangat penting karena beberapa alasan. Pertama, meningkatkan penelitian tentang kepuasan kerja dengan mendeteksi antesedennya (seperti kondisi kerja). Meskipun banyak penelitian sudah dilakukan untuk menyelidiki anteseden kepuasan kerja (Osman et al., 2016), namun penelitian sederhana telah dilakukan untuk menyelidiki pengaruh kondisi kerja terhadap kepuasan kerja (Guan \& Frenkel, 2019). Secara keseluruhan, kesesuaian antara kondisi kerja dengan kepuasan kerja hingga prestasi kerja ini merupakan suatu alur dimana kondisi kerja dapat meningkatkan prestasi kerja.

Penelitian ini menjadi pembuka mata bagi para atasan tentang bagaimana mereka harus mempertimbangkan, taktik yang lebih strategis tentang kondisi kerja serta meningkatkan tingkat kepuasan karyawannya dengan memperhatikan faktor-faktor lain selain ciri fisik kondisi kerja. Dengan meningkatkan tingkat kepuasan, mereka akan memberikan hasil yang lebih baik dalam hal kinerja perusahaan (Raziq \& Maulabakhsh, 2015). Secara keseluruhan, hasil penelitian kami mendukung penelitian sebelumnya dan menarik kesimpulan bahwa tempat kerja mempengaruhi kinerja (Shalley, Gilson, \& Blum, 2000). Kondisi kerja yang tidak menyenangkan di industri jasa memiliki pengaruh yang berbeda-beda terhadap masing-masing indikator prestasi kerja (Kahya, 2007). Penelitian ini menyoroti pentingnya kondisi kerja yang menyenangkan dan tidak menyenangkan yang dirancang untuk meningkatkan kinerja kerja karyawan yang bekerja penuh waktu di industri konstruksi di Jakarta. Kondisi kerja berada di bawah domain kognisi emosional yang mencerminkan apakah tempat kerja konstruktif atau berbahaya bagi kesejahteraan pribadi seseorang (Megías et al., 2017; Stenfors et al., 2013). Hasil kami mengungkapkan bahwa kondisi kerja yang sehat meningkatkan tingkat kepuasan karyawan yang selanjutnya mendorong mereka untuk bekerja dengan baik sesuai kapasitas kerja mereka (Nilsen \& Ringholm, 2019). Manajemen mengabaikan fakta bahwa karyawan mereka adalah sumber daya yang sangat penting dan perlu disediakan lingkungan yang fleksibel untuk melaksanakan pekerjaan mereka secara efisien dan efektif tanpa menimbulkan stres (Raziq \& Maulabakhsh, 2015).

\section{Simpulan}

Penelitian ini mengamati pengaruh langsung kondisi kerja terhadap prestasi kerja dengan mediasi kepuasan kerja. Selain itu, penelitian ini dengan pertimbangan ketat dari literatur sebelumnya telah mengidentifikasi kepuasan kerja sebagai mediator yang dihilangkan untuk diuji di antara kondisi kerja dan prestasi kerja. Penelitian ini menambah literatur prestasi kerja dengan menunjukkan kepuasan kerja memediasi hubungan kondisi kerja dan prestasi kerja.

\section{Daftar Pustaka}

Agarwal, U. A. (2014). Linking justice, trust and innovative work behaviour to work engagement. Personnel Review, 43(1), 41-73. https://doi.org/10.1108/PR-02-2012-0019

Agbozo, G. K., Owusu, I. S., Hoedoafia, M. A., \& Y. B. Atakorah. (2017). The Effect of Work Environment on Job Satisfaction: Evidence from the Banking Sector in Ghana. Journal of Human Resource Management, 5(1), 12. https://doi.org/10.11648/j.jhrm.20170501.12

Ahmed, I. (2010). Effects of Motivational factors on Employees Job Satisfaction: A case study of University of the Punjab, Pakistan. International Journal of Business and Management, 5(3), 70-80. https://doi.org/10.5539/ijbm.v5n3p70

Akhtar, A., Naheed, K., Akhtar, S., \& Farooq, U. (2018). Impact of Job Stress on Employees'Job Satisfaction: An Empirical Study of Private Banksof Pakistan. Pakistan Journal of Social Sciences (PJSS), 38(1), 137-151. Retrieved from https://en.oxforddictionaries.com/definition/stress

Al-Omari, K., \& Okasheh, H. (2017). The Influence of Work Environment on Job Performance: A Case Study of Engineering Company in Jordan. International Journal of Applied Engineering Research, 12(24), 1554415550. Retrieved from https://www.ripublication.com/ijaer17/ijaerv12n24_223.pdf

Armstrong, G. S., Atkin-Plunk, C. A., \& Wells, J. (2015). The Relationship Between Work-Family Conflict, Correctional Officer Job Stress, and Job Satisfaction. Criminal Justice and Behavior, 42(10), 1066-1082. https://doi.org/10.1177/0093854815582221

Atamba, C. (2019). Restorative effects of awe on negative affect after receiving negative performance feedback. Journal of Psychology in Africa, 29(2), 95-103. https://doi.org/10.1080/14330237.2019.1594640

Aziz, I., Kumar, R., Rathore, A., \& Lal, M. (2015). Working Environment and Job Satisfaction Among Health 
Professional Working At a Tertiary Care Hospital of Pakistan. Journal of Ayub Medical College, Abbottabad : JAMC, 27(1), 201-204.

Bakotić, D., \& Fiskovića, C. (2013). Relationship between Working Conditions and Job Satisfaction: The Case of Croatian Shipbuilding Company, 4(2), 206-213.

Baruch-Feldman, C., Brondolo, E., Ben-Dayan, D., \& Schwartz, J. (2002). Sources of social support and burnout, job satisfaction, and productivity. Journal of Occupational Health Psychology, 7(1), 84-93. https://doi.org/10.1037/1076-8998.7.1.84

Bashir, A., Amir, A., Jawaad, M., \& Hasan, T. (2020). Work conditions and job performance: An indirect conditional effect of motivation. Cogent Business and Management, $7(1)$. https://doi.org/10.1080/23311975.2020.1801961

Borman, W. C. (2004). The concept of organizational citizenship. Current Directions in Psychological Science, 13(6), 238-241. https://doi.org/10.1111/j.0963-7214.2004.00316.x

Day, D. V., \& Bedeian, A. G. (1991). Predicting Job Performance Across Organizations: The Interaction of Work Orientation and Psychological Climate. Journal of Management, 17(3), 589-600. https://doi.org/10.1177/014920639101700304

Faragher, E. B., Cass, M., \& Cooper, C. L. (2005). The relationship between job satisfaction and health: A metaanalysis. Occupational and Environmental Medicine, 62(2), 105-112. https://doi.org/10.1136/oem.2002.006734

Górny, A. (2017). The use of working environment factors as criteria in assessing the capacity to carry out processes. MATEC Web of Conferences, 94. https://doi.org/10.1051/matecconf/20179406011

Guan, X., \& Frenkel, S. (2019). How perceptions of training impact employee performance: Evidence from two Chinese manufacturing firms. Personnel Review, 48(1), 163-183. https://doi.org/10.1108/PR-05-2017-0141

Gul, H., Usman, M., Liu, Y., Rehman, Z., \& Jebran, K. (2018). Does the effect of power distance moderate the relation between person environment fit and job satisfaction leading to job performance? Evidence from Afghanistan and Pakistan. Future Business Journal, 4(1), 68-83. https://doi.org/10.1016/j.fbj.2017.12.001

Gulliver, P., Towell, D., \& Peck, E. (2003). Staff morale in the merger of mental health and social care organizations in England. Journal of Psychiatric and Mental Health Nursing, 10(1), 101-107. https://doi.org/10.1046/j.1365-2850.2003.00544.x

Hackman, J. R., \& Oldham, G. R. (1976). Motivation through the design of work: test of a theory. Organizational Behavior and Human Performance, 16(2), 250-279. https://doi.org/10.1016/0030-5073(76)90016-7

Hair, Joe F., Sarstedt, M., Hopkins, L., \& Kuppelwieser, V. G. (2014). Partial least squares structural equation modeling (PLS-SEM): An emerging tool in business research. European Business Review, 26(2), 106-121. https://doi.org/10.1108/EBR-10-2013-0128

Hair, Joseph F., Sarstedt, M., \& Ringle, C. M. (2019). Rethinking some of the rethinking of partial least squares. European Journal of Marketing, 53(4), 566-584. https://doi.org/10.1108/EJM-10-2018-0665

Henseler, J., Ringle, C. M., \& Sarstedt, M. (2015). A new criterion for assessing discriminant validity in variancebased structural equation modeling. Journal of the Academy of Marketing Science, 43(1), 115-135. https://doi.org/10.1007/s11747-014-0403-8

Hoboubi, N., Choobineh, A., Kamari Ghanavati, F., Keshavarzi, S., \& Akbar Hosseini, A. (2017). The Impact of Job Stress and Job Satisfaction on Workforce Productivity in an Iranian Petrochemical Industry. Safety and Health at Work, 8(1), 67-71. https://doi.org/10.1016/j.shaw.2016.07.002

Hu, L. T., \& Bentler, P. M. (1999). Cutoff criteria for fit indexes in covariance structure analysis: Conventional criteria versus new alternatives. Structural Equation Modeling, 6(1), 1-55. https://doi.org/10.1080/10705519909540118

Imran, R., Fatima, A., Zaheer, A., Yousaf, I., \& Batool, I. (2012). How to boost employee performance: Investigating the influence of transformational leadership and work environment in a Pakistani perspective. Middle East Journal of Scientific Research, 11(10), 1455-1462. https://doi.org/10.5829/idosi.mejsr.2012.11.10.741

Inuwa, M. (2016). Job Satisfaction and Employee Performance: An Empirical Approach. The Millennium University Journal, 1(1), 90-103.

Jiménez, P., Winkler, B., \& Dunkl, A. (2017). Creating a healthy working environment with leadership: the concept of health-promoting leadership. International Journal of Human Resource Management, 28(17), 2430-2448. https://doi.org/10.1080/09585192.2015.1137609

Judge, T. A., \& Larsen, R. J. (2001). Dispositional affect and job satisfaction: A review and theoretical extension. Organizational Behavior and Human Decision Processes, 86(1), 67-98. https://doi.org/10.1006/obhd.2001.2973

Jung, H. S., \& Yoon, H. H. (2015). The impact of employees' positive psychological capital on job satisfaction and organizational citizenship behaviors in the hotel. International Journal of Contemporary Hospitality 
Management, 27(6), 1135-1156. https://doi.org/10.1108/IJCHM-01-2014-0019

Kahya, E. (2007). The effects of job characteristics and working conditions on job performance. International Journal of Industrial Ergonomics, 37(6), 515-523. https://doi.org/10.1016/j.ergon.2007.02.006

Kiazad, K., Kraimer, M. L., \& Seibert, S. E. (2019). More than grateful: How employee embeddedness explains the link between psychological contract fulfillment and employee extra-role behavior. Human Relations, 72(8), 1315-1340. https://doi.org/10.1177/0018726718806352

Kissi, E., Agyekum, K., Adjei-Kumi, T., Caleb, D., \& Micheal, E. D. (2020). Exploring the influence of religious elements on performance factors in developing countries: a case of the Ghanaian construction industry. International Journal of Productivity and Performance Management. https://doi.org/10.1108/IJPPM-11-20190546

Law, F. M., \& Guo, G. J. (2016). Correlation of hope and self-efficacy with job satisfaction, job stress, and organizational commitment for correctional officers in the Taiwan prison system. International Journal of Offender Therapy and Comparative Criminology, 60(11), 1257-1277. https://doi.org/10.1177/0306624X15574997

Lu, L., Lu, A. C. C., Gursoy, D., \& Neale, N. R. (2016). Work engagement, job satisfaction, and turnover intentions: A comparison between supervisors and line-level employees. International Journal of Contemporary Hospitality Management, 28(4), 737-761. https://doi.org/10.1108/IJCHM-07-2014-0360

Masa'deh, R., Obeidat, B. Y., \& Tarhini, A. (2016). A Jordanian empirical study of the associations among transformational leadership, transactional leadership, knowledge sharing, job performance, and firm performance: A structural equation modelling approach. Journal of Management Development, 35(5), 681705. https://doi.org/10.1108/JMD-09-2015-0134

Matsuo, M. (2019). Effect of learning goal orientation on work engagement through job crafting: A moderated mediation approach. Personnel Review, 48(1), 220-233. https://doi.org/10.1108/PR-11-2017-0346

Megías, A., Gutiérrez-Cobo, M. J., Gómez-Leal, R., Cabello, R., \& Fernández-Berrocal, P. (2017). Performance on emotional tasks engaging cognitive control depends on emotional intelligence abilities: An ERP study. Scientific Reports, 7(1), 1-9. https://doi.org/10.1038/s41598-017-16657-y

Mustafa, G., \& Ali, N. (2019). Rewards, autonomous motivation and turnover intention: Results from a non-Western cultural context. Cogent Business and Management, 6(1). https://doi.org/10.1080/23311975.2019.1676090

Nilsen, H. R., \& Ringholm, T. (2019). Lost in motivation? The case of a Norwegian community healthcare project on ethical reflection. Cogent Business and Management, 6(1). https://doi.org/10.1080/23311975.2019.1632045

Osman, S., Shariff, S. H., \& Lajin, M. N. A. (2016). Does Innovation Contribute to Employee Performance? Procedia - Social and Behavioral Sciences, 219, 571-579. https://doi.org/10.1016/j.sbspro.2016.05.036

Raziq, A., \& Maulabakhsh, R. (2015). Impact of Working Environment on Job Satisfaction. Procedia Economics and Finance, 23(October 2014), 717-725. https://doi.org/10.1016/s2212-5671(15)00524-9

Røssberg, J. I., Eiring, \& Friis, S. (2004). Work environment and job satisfaction. Social Psychiatry and Psychiatric Epidemiology, 39(7), 576-580. https://doi.org/10.1007/s00127-004-0791-z

Shalley, C. E., Gilson, L. L., \& Blum, T. C. (2000). Matching creativity requirements and the work environment: Effects on satisfaction and intentions to leave. Academy of Management Journal, 43(2), 215-223. https://doi.org/10.2307/1556378

Stenfors, C. U. D., Magnusson Hanson, L., Oxenstierna, G., Theorell, T., \& Nilsson, L. G. (2013). Psychosocial Working Conditions and Cognitive Complaints among Swedish Employees. PLoS ONE, 8(4). https://doi.org/10.1371/journal.pone.0060637

Strömberg, C., Aboagye, E., Hagberg, J., Bergström, G., \& Lohela-Karlsson, M. (2017). Estimating the Effect and Economic Impact of Absenteeism, Presenteeism, and Work Environment-Related Problems on Reductions in Productivity from a Managerial Perspective. Value in Health, 20(8), 1058-1064. https://doi.org/10.1016/j.jval.2017.05.008

Taghipour, A., \& Dejban, R. (2013). Job Performance: Mediate Mechanism of Work Motivation. Procedia - Social and Behavioral Sciences, 84, 1601-1605. https://doi.org/10.1016/j.sbspro.2013.06.796

Trivellas, P., Reklitis, P., \& Platis, C. (2013). The Effect of Job Related Stress on Employees' Satisfaction: A Survey in Health Care. Procedia - Social and Behavioral Sciences, 73, 718-726. https://doi.org/10.1016/j.sbspro.2013.02.110

Wright, T. A., Cropanzano, R., \& Bonett, D. G. (2007). The moderating role of employee positive well being on the relation between job satisfaction and job performance. Journal of Occupational Health Psychology, 12(2), 93104. https://doi.org/10.1037/1076-8998.12.2.93

Yozgat, U., Yurtkoru, S., \& Bilginoğlu, E. (2013). Job Stress and Job Performance Among Employees in Public Sector in Istanbul: Examining the Moderating Role of Emotional Intelligence. Procedia - Social and Behavioral Sciences, 75, 518-524. https://doi.org/10.1016/j.sbspro.2013.04.056 
Yuen, K. F., Loh, H. S., Zhou, Q., \& Wong, Y. D. (2018). Determinants of job satisfaction and performance of seafarers. Transportation Research Part A: Policy and Practice, 110(November 2017), 1-12. https://doi.org/10.1016/j.tra.2018.02.006 